\title{
Spatial and temporal dynamics of the mesozooplankton (Crustacea: Cladocera, Copepoda and Decapoda) in a Pampean shallow hyposaline lake during drought conditions
}

\author{
María Belén Alfonso ${ }^{1}$, Carla Alejandra Baleani ${ }^{1}$, María Clara Menéndez ${ }^{1}$, Fernanda Fornerón² \\ and María Cintia Piccolo ${ }^{1,3}$
}

'Instituto Argentino de Oceanografía, Centro Científico y Tecnológico Bahía Blanca (CONICET-UNS).
Florida 8000, Bahía Blanca (8000), Buenos Aires, Argentina.

${ }^{2}$ Instituto de Formación Docente Continua. Colón y Sargento Cabral S/N. 8361. Luis Beltrán, e Instituto de Formación Docente Continua. Av. Berutti 1150, Río Colorado (8138), Río Negro, Argentina. ${ }^{3}$ Departamento de Geografía y Turismo, Universidad Nacional del Sur. 12 de octubre y San Juan, 1198,

Bahía Blanca (8000), Buenos Aires, Argentina.

E-mail: mbalfonso@iado-conicet.gob.ar

RESUMEN. La laguna Sauce Grande, un lago poco profundo, eutrófico e hiposalino, se estudió mediante muestreos mensuales entre diciembre de 2009 a noviembre de 2010. La sequía que afectó a la región desde 2009 y durante todo el período de estudio interrumpió la entrada regular del río y la salida al Océano Atlántico. La laguna presentó un aumento de los valores de salinidad y condiciones altamente turbias como resultado de las condiciones de sequía y de la resuspensión de sedimento por efecto del viento. Los cladóceros pequeños como Moina micrura y el copépodo Boeckella poopoensis dominaron la comunidad del mesozooplancton. La salinidad determinó la composición del mesozooplancton; mientras tanto, la dinámica de la abundancia estuvo determinada por la temperatura junto con las condiciones eutróficas durante el período de estudio. En un contexto global de cambio climático, y en una región donde la sequía y los ciclos húmedos son frecuentes, estos resultados contribuyen a comprender aún más los procesos que afectan la estructura y dinámica de la comunidad de zooplancton durante eventos climáticos extremos.

Palabras clave: Laguna Sauce Grande, mesozooplancton, salinidad, sequía.

ABSTRACT. The Sauce Grande Lake, a shallow, eutrophic, and hyposaline lake, was studied through monthly samplings during a year (December 2009- November 2010). The drought that affected the region since 2009 and during the entire study period interrupted the regular inflow from the river and outflow to the Atlantic Ocean. The lake presented an increase of salinity values and highly turbid conditions as a result of the drought conditions and wind resuspension. Small cladocerans such as Moina micrura and the copepod Boeckella poopoensis dominated the mesozooplankton community. The salinity determined the mesozooplankton composition; meanwhile, the abundance dynamic was ruled by temperature in conjunction with the eutrophic conditions during the study period. In a global context of climate change, and in a region where drought and wet cycles are frequent, these results further contribute to understanding the processes affecting the zooplankton community structure and dynamics during extreme climate events.

Keywords: Drought, mesozooplankton, salinity, Sauce Grande Lake. 


\section{INTRODUCTION}

Shallow lakes are the most abundant lake types in the global landscape (Downing et al., 2006). Lakes in the Pampas, a broad and fertile plain in Argentina, are mostly polymictic and present high nutrient levels, ranging from eutrophic to highly hypertrophic (Quirós \& Drago, 1999). The Pampa Plain is the most highly developed agricultural region in Argentina, which contributes even more to the eutrophication process of the area (Quirós et al., 2002). The occurrence of long periods of droughts and floods characterizes the region, and affects water availability, the productivity of agricultural systems, and other human activities (Aliaga et al., 2017).

Plankton is an essential indicator of the structure and function of lake ecosystems and their ecological status (Jeppesen et al., 2011). The copepods (cyclopoids and calanoids) and cladocerans dominate the mesozooplankton fraction (200-2000 $\mu \mathrm{m})$ in the Pampas shallow lakes (Chaparro et al., 2011; Diovisalvi et al., 2015). The cyclopoid Acanthocyclops robustus (Sars, 1863) and the calanoid Notodiaptomus incompositus Brian, 1925 have significant occurrence (Menu Marque, 2000). Cladocera is represented by genera such as Bosmina, Ceriodaphnia, Daphnia, Diaphanosoma, Moina and members of Chydoridae. Cladocerans are particularly abundant at places or periods with low planktivore fish abundance (Diovisalvi et al., 2015; Sosnovsky et al., 2010), as well as in lakes densely colonized by submerged macrophytes (Ardohain, 2008). The predation by fish and invertebrates in conjunction with physicochemical variables can interactively affect the dynamic and structure of the mesozooplankton. Mainly, salinity changes the composition of plankton community (Jeppesen et al., 2015).The species richness of zooplankton decreases with increasing salinity (Brucet et al., 2009) and thereby, the trophic interactions in lakes is modified (Alfonso et al., 2017; Brucet et al., 2009; Jeppesen et al., 2007a). In hyposaline waters, the predominant taxa are halotolerant freshwater forms, and species richness and composition are highly correlated with salinity (Jensen et al., 2010). At high salinities, the zooplankton communities are often dominated by small-bodied such as small cladocerans (e.g., Bosmina and Ceriodaphnia) and rotifers, which are less efficient phytoplankton controllers (Brucet et al., 2009; Jeppesen et al., 2007b). Meanwhile, salt intolerant large-bodied cladocerans such as Daphnia are restricted (Frey, 1993), except for some species such as $D$. spinulata Birabén, 1917 which tolerate changes in salt concentration (Echaniz et al., 2009) and can be found in oligohaline and mesohaline environments (Hoffmeyer, 2004). Despite the well-known impact of salinity determining community structure, studies have indicated that other physicochemical variables of saline lakes could play a critical role controlling the zooplankton community (Williams, 1998). Other factors, such as habitat permanence, water management, incorporation of freshwater input (enriched by nutrients related to anthropogenic use) and trophic interactions alter the structure of aquatic communities in saline lakes (Alfonso et al., 2017; Echaniz et al., 2009; Larson \& Belovsky, 2013; Stenger-Kovács et al., 2014). Zooplankton species richness increases with nutrient enrichment in saline lakes, demonstrating the importance of nutrient supply (Larson \& Belovsky, 2013). Furthermore, the depth of a shallow lake can be subject to extreme fluctuations resulting from climatic variability. Water-level variation emerges such as a decisive hydrology factor; mainly in shallow lakes located in wetlands particularly sensitive to a quick change in depth and water input (Leira \& Cantonati, 2008). Therefore, the water level fluctuations may have a significant effect on the ecology, functioning, and management of shallow lakes. On the other hand, anthropogenic factors like water use may actively modify the amplitude of water level fluctuations with impact on the ecological status of the lake (Del Ponti et al., 2015). Numerous investigations highlight the importance of the lake's depth for shifts between submerged macrophytes and turbid states in shallow lakes (Scheffer \& van Nes, 2007). Nutrient concentrations (nitrogen and phosphorus) vary with water levels (Nõges et al., 2003) and increase during drought periods (Tan \& Beklioglu, 2005). The significant contact of water with sediments 
related to low water level and prolonged water residence may enhance the nutrient internal release (Romo et al., 2005). According to the IPCC (2007), climate change is likely to increase the risk of droughts and floods. For this reason, the knowledge about climate variability impact and the consequential flood and drought periods affecting water level, physicochemical parameters, and zooplankton community is crucial to assess the shift magnitude in the forthcoming environmental conditions.

We expect that the composition and the spatial and temporal dynamic of the mesozooplankton will reflect extreme conditions (water level diminution, salinity and eutrophication increase) during extraordinary drought events at Sauce Grande Lake. The results could be useful for establishing a baseline to future monitoring and water management decisions of the lake.

\section{MATERIAL AND METHODS}

\section{Study site}

The Sauce Grande shallow lake (38⒌ ' S, $61^{\circ} 24^{\prime}$
W) is located at SE of Buenos Aires Province, Argentina (Figure 1). It is a natural water body with a surface area of $21.55 \mathrm{~km}^{2}$ and a maximum depth of $3 \mathrm{~m}$ (Fornerón et al., 2010b). This lake is polymictic, rich in dissolved oxygen, turbid, and eutrophic (Ferrer et al., 2012; Fornerón et al., 2010a). The lake has an affluent, the Sauce Grande River, and a connection with the Atlantic Ocean. During the drought of 2008-2009 (Fornerón, 2010a), the high evaporation rate and the water use for irrigation generated the loss of both connections, and the lake evolved from a drainage lake to an isolated lake. It is a prolonged depression, with low shoreline and smooth slope, and colonized by reeds. The presence of the planktivorous fish Odontesthes bonariensis (Valenciennes, 1835) is frequent (Remes Lenicov \& Colautti, 2003). The climate of the region is temperate, with mild winters and warm summers. The mean annual temperature ranges between 14 and $20^{\circ} \mathrm{C}$ (Aliaga et al., 2016). Wet and dry cycles characterize the region. Total annual precipitation ranges from 500 to $650 \mathrm{~mm}$ (Aliaga et al., 2016).

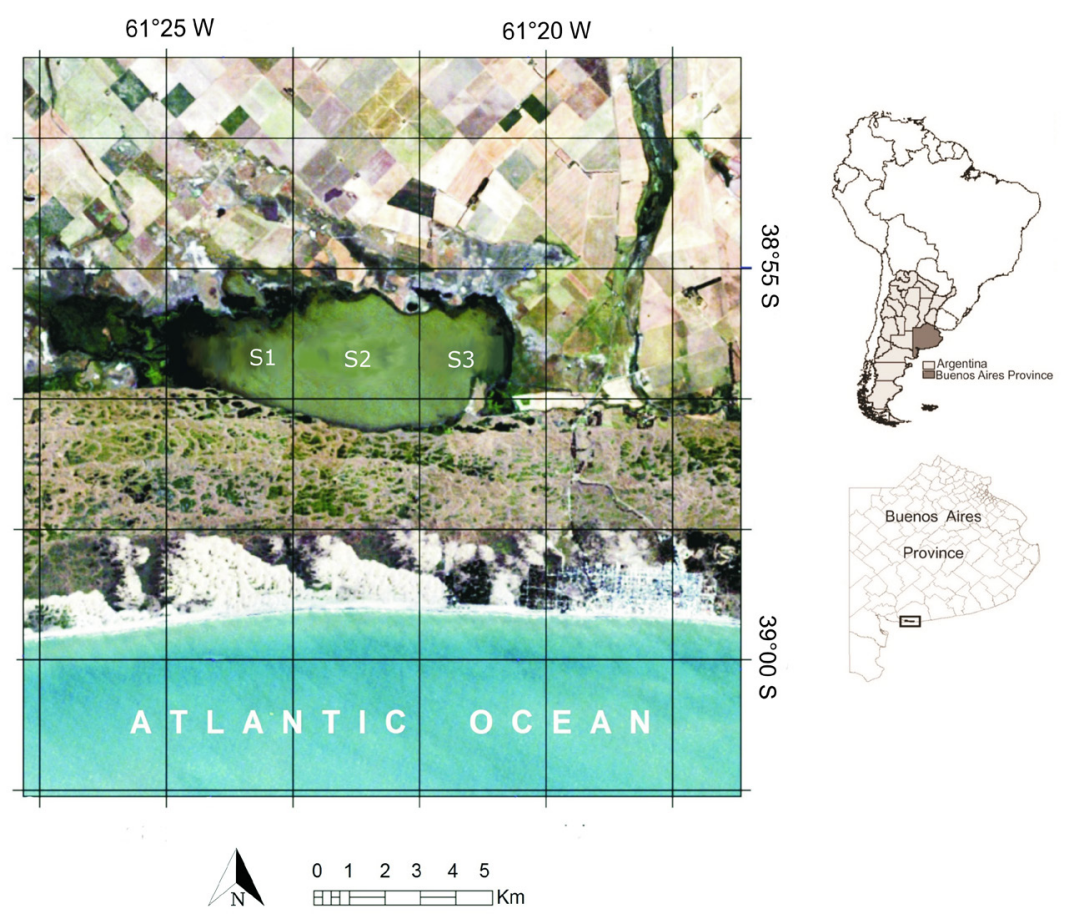

Figure 1. Location of the Sauce Grande Lake and of sampling stations (S1, S2, S3).

Figura 1. Ubicación geográfica de la laguna Sauce Grande y de las estaciones de muestreo (S1, S2, S3). 


\section{Environmental variables}

Monthly samplings were carried out from December 2009 to November 2010, including the four seasons: summer (December 2009 to February 2010), autumn (March 2010 to May 2010), winter (June 2010 to August 2010), and spring (September 2010 to November 2010). Three sites were sampled across the central axis of the lake: (S1) near the inflow of the Sauce Grande River (S2) at the deepest zone of the lake and (S3) near the river outflow into the sea (Figura 1). Water temperature, conductivity, turbidity, dissolved oxygen (DO), and $\mathrm{pH}$ were measured in situ using a multisensor Horiba U-10. Also, the concentration of chlorophyll $a(\mathrm{Chl} a)$, suspended particulate matter (SPM), particulate organic matter (POM) and dissolved inorganic nutrients (soluble reactive phosphorus, nitrate, and nitrite) were obtained from surface water samples. The chlorophyll $a$ was extracted with acetone $90 \%$ and measured spectrophotometrically according to the method described in APHA (2005). Soluble reactive phosphorus (SRP) and total dissolved phosphorus (TDP) were determined by the ascorbic acid method. The last fraction was digested with acidic persulphate (APHA, 2005). Nitrate and nitrite were measured by $\mathrm{Cd}$ reduction, followed by diazotization (APHA, 2005). SPM was determined from water samples filtrated through pre-combusted Whatman ${ }^{\mathrm{TM}} \mathrm{GF} / \mathrm{F}$. POM was determined, according to Strickland \& Parsons (1968). Water transparency was estimated with a Secchi disk (SDD). The trophic state indices were calculated considering Carlson equations (Carson, 1977) for $\mathrm{Chl} a$ concentration $(\mu \mathrm{g} / \mathrm{L})$ and SDD measurements in meters.

\section{Plankton sampling and analysis}

Mesozooplankton samples were collected at each site using a $200 \mu \mathrm{m}$ net with a flow meter General Oceanics ${ }^{\circledR}$. A previous study showed that this is a polymictic lake (Fornerón, 2016), so, as the entire column is mixed, the net was horizontally towed at the upper layer for 5 minutes at $2 \mathrm{~m} / \mathrm{s}$, considering it as representative of the entire water column. The collected material was immediately preserved in a buffered solution of $4 \%$ formaldehyde. All samples were examined under a Nikon SMZ 1500 stereoscopic microscope and a Nikon Eclipse 80i microscope $(100 \mathrm{x})$ for specimen identification (Bayly, 1992; Einsle, 1996, among others). The quantitative analysis was carried out in a $5 \mathrm{~mL}$ Bogorov chamber. The number of aliquots was estimated according to Cassie (1971). Copepod individuals were separately counted (nauplii, copepodites and adults).

\section{Statistical analysis between limnological variables and mesozooplankton}

The non-parametric analysis of variance (Kruskal-Wallis) was computed to test for significant differences in the limnological variables and mesozooplankton abundances between the sampling sites. Spearman's rank correlation coefficient ( $r$ ) was used to estimate the relationship between limnological variables and mesozooplankton abundance. A detrended correspondence analysis (DCA) showed a linear response to the biological data; then, an RDA was performed to analyze which of the estimated environmental variables were responsible for the variation in the plankton community. Collinear variables, as defined by an inflation factor $>4$ (TerBraak, 1988), were removed from the analysis. Zooplankton data were not transformed so as not to downweight abundant species. The significance of canonical axes was determined using Monte Carlo randomization with 9999 permutations under the reduced model. P values $<0.05$ were considered statistically significant. Variables that did not contribute to the model at this significance level were removed. The analysis was performed with InfoStat ${ }^{\circledR}$ free version for students (Balzarini et al., 2016) and CANOCO software version 4.53 (Licence number 5741).

\section{RESULTS}

\section{Environmental variables}

During the entire study period, the lake was under severe drought. Both the water flow from the river through the lake and the connection with the Atlantic Ocean were interrupted. 


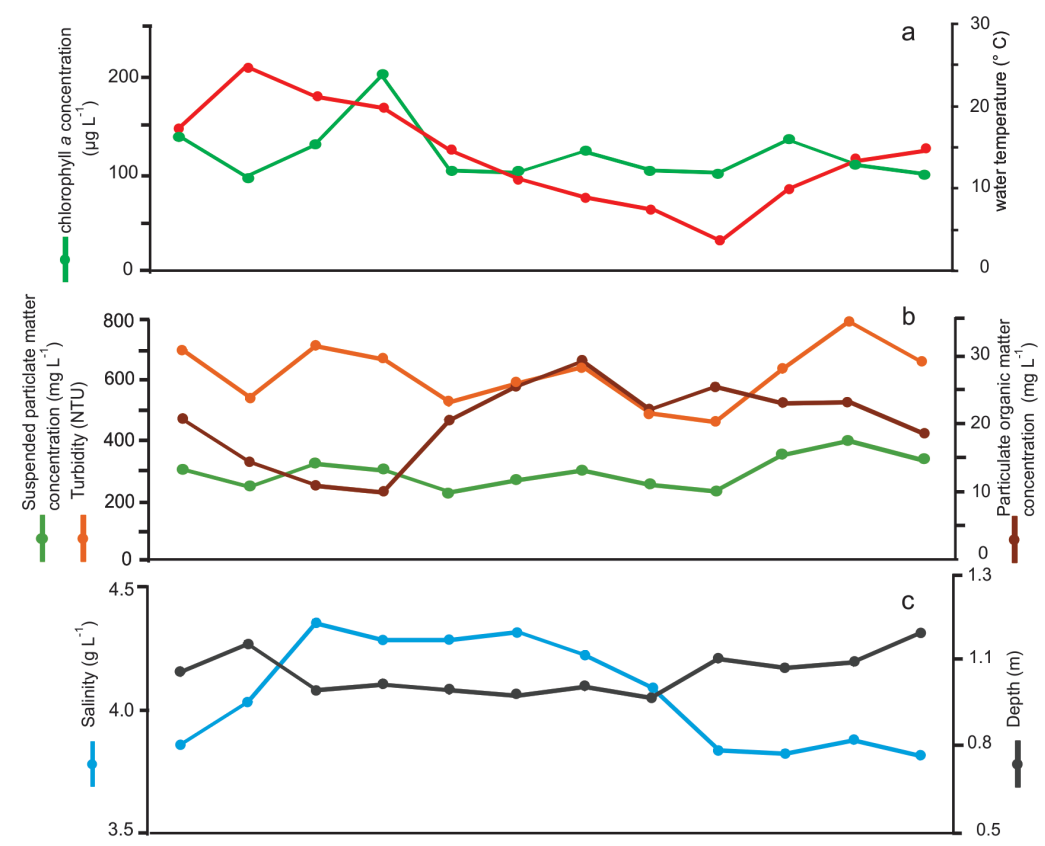

d
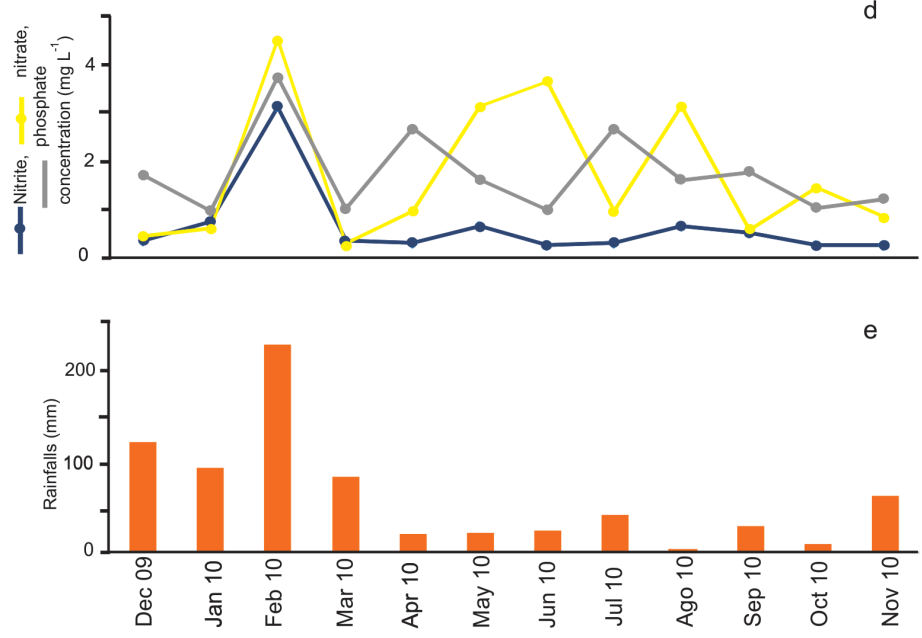

Figure 2. Temporal variation of the monthly mean values of: a. Chl $a$ and water temperature, $\mathbf{b}$. suspended particulate matter (SPM), particulate organic matter (POM) and turbidity, c. depth and salinity, $\mathbf{d}$. nitrates, nitrites and phosphates and e. precipitation in the Sauce Grande Lake during the study period.

Figura 2. Variación temporal de: a. Clorofila a y temperatura del agua, b. materia particulada en suspensión (SPM), materia orgánica particulada (POM) y turbidez, c. profundidad y salinidad, d. nitratos, nitritos, fosfatos y e. precipitaciones en la laguna Sauce Grande durante el período de estudio.

Historically, it has a maximum depth of near 3 $\mathrm{m}$; nevertheless, the lake did not exceed the 1.2 $m$ depth during the study period.

Physicochemical variables did not show significant differences between sampling sites except for depth $(p<0.001)$ and POM $(p<0.05)$. The annual mean water temperature was $14.4^{\circ} \mathrm{C}$ and presented a clear seasonal pattern, ranging from $4.1^{\circ} \mathrm{C}$ (August) to $25.3^{\circ} \mathrm{C}$ (January) (Figure 2a). Mean, minimum, and maximum values and standard deviation of the limnological variables are given in Table 1. DO concentrations were high during the entire study period, with a mean value of $9.8 \mathrm{mg} / \mathrm{L}$ (Table 1). Chl $a$ values 
Table 1. Mean values with standard deviation (SD) and minimum ( $\mathrm{min}$ ) and maximum (max) values of limnological variables recorded at Sauce Grande Lake during the study period.

Tabla 1. Valores medios con desviación estándar (SD) y valores mínimos y máximos de variables limnológicas registradas en la laguna Sauce Grande durante el período de estudio.

\begin{tabular}{lcccc}
\hline & mean & SD & min & max \\
\hline Water temperature $\left({ }^{\circ} \mathrm{C}\right)$ & 14.45 & 6.14 & 4.13 & 25.33 \\
$\mathrm{pH}$ & 8.98 & 0.14 & 8.75 & 9.14 \\
Depth $(\mathrm{m})$ & 1.07 & 0.07 & 0.98 & 1.21 \\
Salinity (g/L) & 4.06 & 0.21 & 3.81 & 4.34 \\
Chl $a(\mu \mathrm{g} / \mathrm{L})$ & 120.79 & 29.45 & 97.37 & 201.50 \\
Dissolved oxygen (mg/L) & 9.84 & 1.67 & 7.37 & 12.38 \\
Turbidity & 621.22 & 100.20 & 461.80 & 796.80 \\
Secchi disk (m) & 0.25 & 0.03 & 0.17 & 0.30 \\
Suspended particulate matter (mg/L) & 294.0 & 53.4 & 226.0 & 400.0 \\
Particulate organic matter (mg/L) & 20.18 & 5.90 & 9.81 & 29.06 \\
Nitrites ( $\mu$ mol/L) & & & & \\
Nitrates $(\mu$ mol/L) & 0.63 & 0.80 & 0.24 & 3.11 \\
Phosphates ( $\mu$ mol/L) & 1.69 & 1.47 & 0.27 & 4.50 \\
Trophic state indices (chlorophyll $\alpha)$ & 86.41 & 2.07 & 84.52 & 91.65 \\
Trophic state indices (secchi disk) & 79.93 & 2.18 & 77.48 & 85.75 \\
\hline
\end{tabular}

were also high, with a mean value of $120.8 \mu \mathrm{g} /$ $\mathrm{L}$, with the maximum concentration in March and the lowest in January (Table 1, Figure 2a). The $\mathrm{pH}$ was always alkaline. Transparency was low, with a mean SDD value of $25 \mathrm{~cm}$ related to high SPM and POM values (Table 1). The SPM presented the highest value in spring and the lowest one in autumn (Table 1, Figure 2b). Mean POM was $20.2 \mathrm{mg} \mathrm{C/L}$, with maximum values in winter and minimum in autumn (Table 1, Figure 2b). Depth was low and oscillated between 1 and $1.2 \mathrm{~m}$ (Figure 2c). During February, March, and May in S3, the lake presented minimum depths and maximum in November in S2.
Salinity mean value was $4 \mathrm{~g} / \mathrm{L}$, classifying this lake as hyposaline according to Hammer (1986). Nutrient concentrations were high (Table 1) during all the study period but did not present a clear temporal pattern (Figure 2d). Precipitation was minimum in August ( $3 \mathrm{~mm}$ ) and maximum in February (225 mm). Wind speed's minimum values were registered in summer $(5 \mathrm{~km} / \mathrm{h})$ and maximum in spring $(24 \mathrm{~km} / \mathrm{h})$. According to Carlson's TSI indexes, the lake is eutrophic (Table 1). TSIchl varied between 84.5 (January 2010) and 91.65 (March 2010). TSIsd varied between 77.5 (January 2010) and 85.75 (March 2010). The Spearman's correlation analysis 
showed that water temperature was positively correlated with precipitation $(p<0.01)$ and negatively with $D O(p<0.001), p H(p<0.05)$, POM $(p<0.001)$ and phosphate concentration ( $p$ $<0.05$ ). Also, turbidity was positively correlated with wind speed $(p<0.01)$. SDD also showed a significant negative correlation with $\mathrm{Chl} a$ ( $\mathrm{p}<$ $0.001)$. Salinity was negatively correlated with depth $(p<0.01)$.

\section{Mesozooplankton composition and spatiotemporal dynamics}

Eight taxa distributed in four orders: Anomopoda, Calanoida, Cyclopoida, and Decapoda represent the mesozooplankton community. Mesozooplankton abundance showed significant differences between months but not significant between sampling points ( $p>0.7$ ).
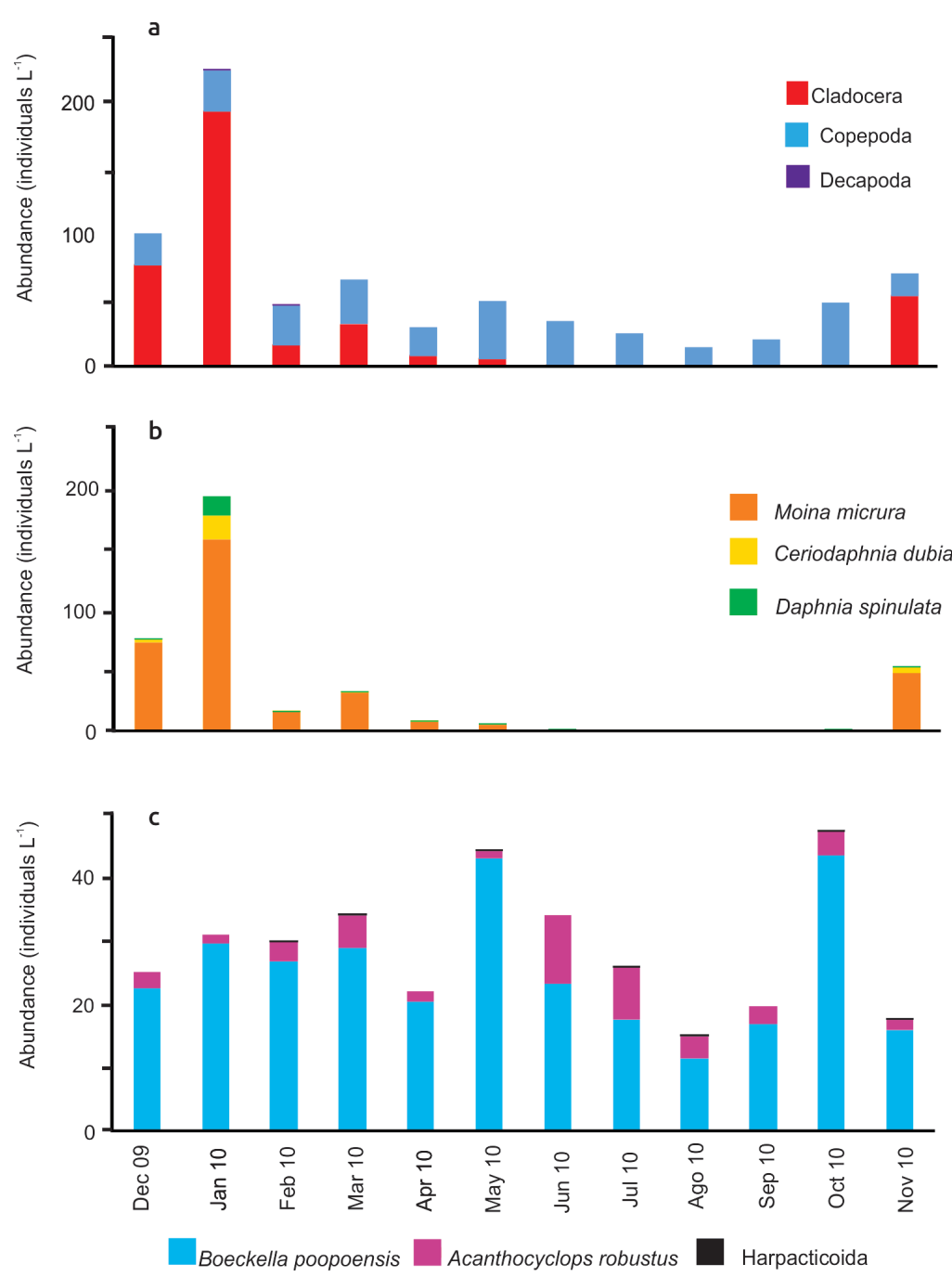

Figure 3. Mean mesozooplankton abundance recorded in Sauce Grande lake during the study period: a. Copepoda, Cladocera, and Decapoda monthly abundance, b. Cladocera species monthly abundance and c. Copepoda species monthly abundance.

Figura 3. Abundancia media del mesozooplankton registrada en la laguna Sauce Grande durante el período de estudio: a. Abundancia mensual de Copepoda, Cladocera y Decapoda, b. Abundancia mensual de las especies de Cladocera y c. Abundancia mensual de las especies de Copepoda. 
Cladocerans predominate in the warmer period (December 2009, January 2010 and November 2010), while cyclopoids and calanoids were consistent all year, especially in cold months, when cladocerans were barely present (Figure 3a). Total species richness was similar during the study period, fluctuating between five species in January and April, and seven species in May, October, and November when low salinity values were also registered (Figure 4).

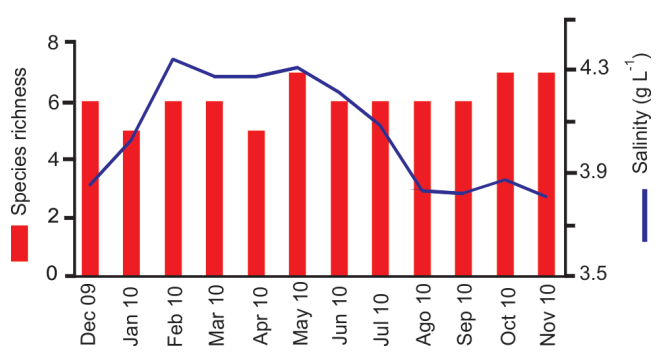

Figure 4. The temporal variation of total species richness and salinity concentration during the study period in the Sauce Grande Lake.

Figura 4. Variación temporal de la riqueza total de especies y de la salinidad durante el período de estudio en la laguna Sauce Grande.

In contrast, mesozooplankton abundance was slightly variable (15.5 - 225 ind/L). The lowest value was recorded in winter (August 2010), while the highest one in summer (January 2010) (Figure 3a). Four species of cladocerans were present, which represented $52.9 \%$ of the total mesozooplankton abundance. Moina micrura Kurz, 1874 was the most abundant taxon (Figure $3 b)$, representing $46 \%$ of the total density. The highest abundance of this species was recorded in January (158.5 ind/L), whereas the minimum in September ( $<1$ ind/L). It is essential to mention that individuals of $M$. micrura with ephippia structures were observed during all the months the species was recorded. The cladoceran Ceriodaphnia dubia Richard, 1894 represented $4.7 \%$ of the total mesozooplankton abundance with values ranged from under $1 \mathrm{ind} / \mathrm{L}$ (July) to $20.2 \mathrm{ind} / \mathrm{L}$ (January). Daphnia spinulata represented only $2.2 \%$ of the total mesozooplankton abundance, and it was always presented with low number ( $<1$ ind/L). Leydigia louisi louisi Jenkin, 1934 represented only $0.1 \%$ of the total mesozooplankton abundance and its density ranged between 0 and $0.5 \mathrm{ind} / \mathrm{L}$ (Figure 3b).

Copepods (adults, copepodites, and nauplii) represented $47.1 \%$ of the total mesozooplankton abundance. Boeckella poopoensis Marsh, 1906 (Figure 3c) was the most representative (40.6\%), with densities ranging between 11.47 (August) and 43.4 ind/L (October) (Figure 3c). The cyclopoid $A$. robustus (Figure 3c) (6.4\%) showed a maximum of $10.9 \mathrm{ind} / \mathrm{L}$ in June and a minimum of 1.33 ind/L in May (Figure 3c). Harpacticoids represented only $0.05 \%$ of total mesozooplankton abundance, with values minor than $1 \mathrm{ind} / \mathrm{L}$. Their presence was intermittent during the study period (Figure 3c). Finally, Decapoda individuals were represented by Caridea postlarval individuals and were only observed in summer and with low number (January and February, $<1$ ind/L).

\section{Relationship between mesozooplankton and environmental variables}

Cladocerans and carideans presented a strong seasonality. Moina micrura, C. dubia, D. spinulata and Caridea were positively correlated with temperature $(p<0.01, p<0.05, p<0.05$, respectively) meanwhile $L$. louisi louisi was negatively correlated $(p<0.05)$. Also, M. micrura was positively correlated with precipitation ( $p<$ $0.01)$ and negatively with POM $(p<0.05)$. L. louisi louisi was negatively correlated with salinity $(p<0.05)$. Decapoda presented a negative correlation with $\mathrm{pH}(\mathrm{p}<0.05)$. Copepods did not present correlation with the evaluated environmental variables.

The first two axes of the RDA explained the $74.4 \%$ of total variance $(p=0.025)$. The ordination of the sampling dates along the first axis (45.2\%; $p=0.03)$ was associated with temperature $(p=0.05)$ and $\mathrm{pH}(\mathrm{p}=0.04)$, and in the second axis $(29.2 \% ; p=0.048)$ with salinity $(p=0.05)$, nitrate $(p=0.05)$, phosphate $(0.04)$, turbidity $(p=0.04)$, and depth $(p=0.03)$ (Figure $5)$. Cladocerans were associated with hightemperature values; meanwhile, Harpacticoida and Decapoda were associated with low depth 


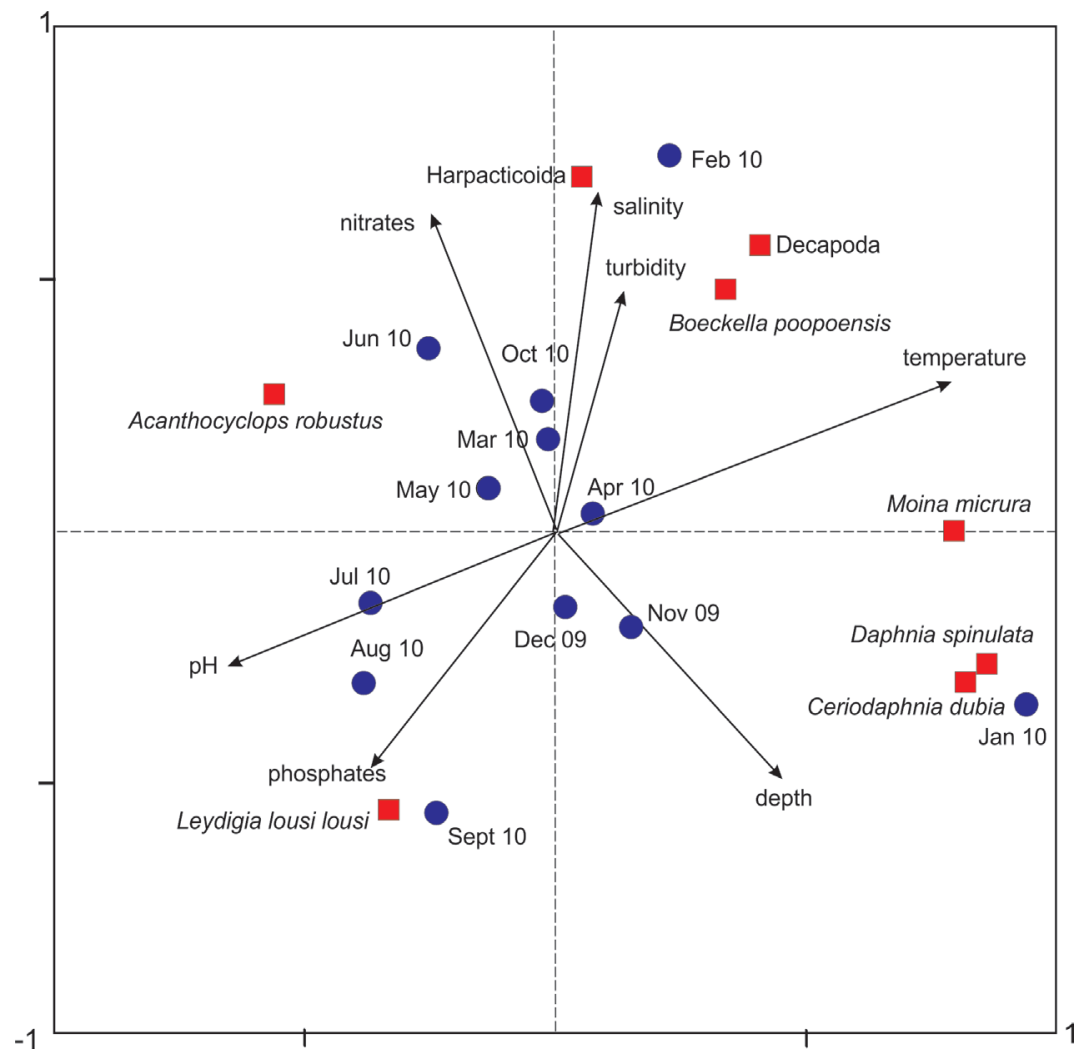

Figure 5. Result of Redundancy analysis (RDA) (first and second axis) based on mesozooplankton abundance and main environmental variables measured during the study period.

Figura 5. Resultado del análisis de Redundancia (RDA) (primer y segundo eje) basado en las abundancias del mesozooplancton y las principales variables ambientales registradas durante el período de estudio.

and high values of salinity, turbidity and nitrate concentration. Acanthocyclops robustus presented the abundance peaks in autumn and winter samples. Finally, spring samples were characterized by the presence of $L$. louisi louisi, with low salinity conditions, and high $\mathrm{pH}$ and phosphate values (Figure 5).

\section{DISCUSSION}

Shallow lakes are particularly vulnerable to drought conditions due to their large surface: volume ratio (Jeppesen et al., 2009). Drought and wet cycles produce concentration and dilution processes in the pampean lakes because of the changes in precipitation and evaporation rates (Aliaga et al., 2016). A salinity increase was observed in the lake respect to previous studies that reported the lake as a subsaline system with $2 \mathrm{~m}$ of depth (Remes Lenicov y Colautti, 2003). It is well known that this kind of drastic reduction in water level produces a concentration of the substances in the lake, which has a high impact on the physicochemical conditions and consequently, in the plankton community (Beklioglu et al., 2007; Jeppensen et al., 2015). Also, like other lakes in the region, Sauce Grande presented highly turbid conditions (Diovisalvi et al., 2010; Echaniz et al., 2008, 2009). Because of its shallow depth, the wind action produces the resuspension of sediments in the water column (Margalef, 1983). The high Chl $a$ values found during this study were coherent with the phytoplankton abundance values found in the lake (Ferrer et al., 2012). This also evidences the high productivity and eutrophic conditions of the lake during the entire study period. 
The mesozooplankton community of the Sauce Grande Lake presented a typical species association from hyposaline lakes of the Pampas (Echaniz et al., 2008; Vignatti et al., 2007). It was characterized by the presence of small cladocerans as $M$. micrura and $C$. dubia (Petrusek et al., 2004), and the halophile copepod B. poopoensis. The large cladoceran $D$. spinulata considered typical of cold-mesohaline waters of Argentina (Olivier, 1962) and the small Chydoridae, L. louisi louisi were also found. The latter was only cited for Hinojales and Nahuel Rucá Lakes in the Pampas (González Sagrario \& Ferrero, 2013) and Patagonian region (Santa Cruz province) (Kotov, 2003). Studies in the Afro-tropical area (Kenya) and the Neotropical Region in Guatemala and Central Mexican highlands (Elías-Gutiérrez et al., 2006, Kotov, 2003) also mention this species, evidencing a significant range of climatic conditions. Among copepods, the halotolerant $B$. popooensis is a common species of saline lakes $(5-90 \mathrm{~g} / \mathrm{L})$, and it is frequent in hyposaline lakes such as Sauce Grande but at higher abundances (Echaníz et al., 2009; Vignatti et al., 2012). The cyclopoid $A$. robustus is an omnivorous species characteristic of eutrophic systems (Caramujo \& Boavida, 1999, Lacroix \& Lescher-Moutoue, 1991) such as Sauce Grande Lake. Finally, Caridea postlarval individuals were also present but only at the highest salinities during January and February and at low number. Caridea is a diverse and significant ecological group that evolved in the sea and invaded brackish coastal, estuarine, and limnetic habitats (Augusto et al., 2007; Freire et al., 2003). Freshwater-inhabiting shows physiological characteristics that may indicate their recent evolutionary history in this habitat. In particular, tolerance to high salinities, dependence on saline water for larval development, and reproductive migrations towards the sea (Bauer \& Delahoussaye, 2008), possibly explain their presence at maximum salinity values during the study period. In a previous study in Sauce Grande Lake, Remes Lenicov \& Colautti (2003) described the zooplanktonic community with dominance of small cladocerans (Bosmina sp.). Also, the presence of Alona sp. and C. dubia were recorded. With respect to copepods, the study also cited the presence of $A$. robustus but in conjunction with Notodiaptomus incompositus (Brian, 1925), a calanoid commonly cited in the Pampean Region for subsaline and permanent lakes (Pilati, 1997). The increases in salinity values observed during the present study could explain the replacement of $N$. incompositus by the halotolerant calanoid $B$. poopoensis and the modifications in cladoceran composition.

The mesozooplankton abundances registered here were lower than other saline lakes (Arora \& Mehra, 2009; Del Ponti et al., 2015; Echaniz et al., 2009, 2012). Particularly, the abundances of C. dubia and A. robustus were lower compared with the results obtained by Remes Lenicov \& Colauti (2003) in the same lake. The zooplankton richness was low and similar to that reported in other hyposaline lakes (Arora \& Mehra, 2009, Del Ponti et al., 2015, Echaniz et al., 2012). The species richness decreased in the months with highest salinity values, as expected. Increased salinity causes osmotic stress accompanied by high mortality or lower reproduction and growth rates (Jeppesen et al., 2007a), and may also promote Cyanobacteria blooms (Sellner et al., 1988). These conditions can induce a state shift to turbid water period (Jeppesen et al., 2007b) and a significant reduction of the resilience of the lake ecosystem. Salinity, in conjunction with high temperature and $\mathrm{pH}$ conditions and low dissolved nitrogen concentrations, can stimulate the appearance of cyanobacterial blooms, as it is frequently reported for lakes undergoing severe droughts (Paerl \& Huisman, 2009; Unrein et al., 2010). Ferrer et al. (2012) recorded the presence of potential toxic cyanobacteria bloom producers such as species of Anabaena, Anabaenopsis, Aphanocapsa and Microcystis in the lake for the same period.

Shallow lakes biota is usually highly diverse due to a more extensive littoral zone (Wetzel, 1999). Nevertheless, the reduction of the lake area by drought conditions could lead to a decrease of the different habitat choices and refuge for mesozooplankton, possibly promoting a detrimental decline in species richness (Rocha Sousa et al., 2013). In the Sauce Grande Lake, the reduction in the basin size, water depth, and the salinity increase by the drought conditions are probably responsible 
for the comparatively low species richness and abundance of mesozooplankton with respect to other pampean eutrophic lakes (Chaparro et al., 2011). The individuals of M. micrura with ephippia structures recorded during the entire study period also indicate the adverse conditions that this lake presented during the drought period.

The predominance of small size taxa characterizes the zooplankton community when planktivores fishes such as Odontesthes bonariensis dominate the pelagic fish assemblages (Iglesias et al., 2011). The grazing pressure of silverside populations is high because during the larval and juvenile stages the diet consists mainly of large planktonic cladocerans and secondarily of adult copepods (calanoids and cyclopoids) (Grosman \& González Castelain 1996; Grosman et al., 2002). Consequently, the predominance of median and small zooplankters with low filtration efficiency is related to a turbid state period (Echaniz \& Vignatti, 2010; Jeppesen et al., 2007a, b) frequently established in the lake. Although the fish community was not studied here, this is like the results found in this lake, for both 2003 and 2010, with a mesozooplankton community dominated by small size cladocerans and low transparency values during all the study period. Daphnia spinulata is the only large cladoceran recorded in this study but only with low density during spring and summer indicating an enhanced fish predation pressure (Jeppesen et al., 1999). These results coincide with those reported for other shallow lakes of the region (e.g., Echaniz \& Vignatti, 2010; Diovisalvi et al., 2015).

In conclusion, the mesozooplankton composition in the Sauce Grande Lake during an extreme drought event was determined by salinity conditions; meanwhile, the abundance dynamic was ruled by temperature in conjunction with the prevailing eutrophic conditions during the study period. In a global scenario of climate change where an increase of extreme events is expected, and for a region where drought and wet cycles are frequent, these results contribute to the understanding of some processes affecting the zooplankton community during extreme drought events. Increased salinity generated by extreme drought events could change the trophic structure of shallow lakes, reducing the lake ecosystem resilience.

\section{ACKNOWLEDGMENTS}

We kindly thank to C. Marinone and S. MenuMarque (Universidad de Buenos Aires) for their valuable help with the mesozooplankton identification, and to Rosemary Scoffield for the English grammar corrections. Grants from ANPCyT, Universidad Nacional del Sur (PGI 24/ G059), PIO CONICET-UNS 2016-2017, and the Inter-American Institute for Global Change Research (IAI) CRN3038 (under US NSF Award GEO-1128040) provide partial support for the studies dealing with the article.

\section{REFERENCES}

Alfonso, M. B., Zunino, J. \& Piccolo M. C. (2017). Impact of water input on plankton temporal dynamics from a managed shallow saline lake. Annales de Limnologie-International Journal of Limnology, 53: 391-400. https://doi.org/10.1051/ limn/2017023

Aliaga, V., Ferrelli, F., Alberdi Algarañaz, E. D., Bohn, V. Y. \& Piccolo, M. C. (2016). Distribución y variabilidad de la precipitación en la región pampeana argentina. Cuadernos de Investigación Geográfica, 42: 261-280. http:// dx.doi.org/10.18172/cig.2867

Aliaga, V. S., Ferrelli, F., \& Piccolo, M. C. (2017) Regionalization of climate over the Argentine Pampas. International Journal of Climatology, 37:1237-1247. http://dx.doi.org/10.1002/joc. 5079

American Public Health Association APHA. (2005). Standard Methods for the Examination of Water and Wastewater, 20th edition. Washington, D.C.

Ardohain, D. M. (2008). Respuesta del zooplancton en su estructura y dinámica a factores clave en una laguna arreica (pcia. de Buenos Aires). Tesis Doctoral N 961. Facultad de Ciencias Naturales y Museo, Universidad Nacional La Plata. 272 pp. 
Arora, J. \& Mehra, N. K. (2009). Seasonal dynamics of zooplankton in a shallow eutrophic, manmade hyposaline lake in Delhi (India): role of environmental factors. Hydrobiologia, 626: 27-40.

Augusto, A., Greene, L. J., Laure, H. J., \& McNamara, J. C. (2007). The ontogeny of isosmotic intracellular regulation in the diadromous, freshwater palaemonid shrimps, Macrobrachium amazonicum and M. olfersi (Decapoda). Journal of Crustacean Biology, 27: 626-634. https://doi.org/10.1651/S-2796.1

Balzarini, M. G., Di Rienzo, J., Tablada, M., Gonzalez, L. A., Bruno, C., Córdoba, M., Robledo, W. y Casanoves, F. (2016). Estadística y biometría: ilustraciones del uso de InfoStat en problemas de agronomía. Buenos Aires: Editorial Brujas.

Bauer, R. T. \& Delahoussaye, J. (2008). Life history migrations of the amphidromous river shrimp Macrobrachium ohione from a continental large river system. Journal of Crustacean Biology, 28: 622-632. https://doi.org/10.1651/08-2977.1

Bayly, I.A.E. 1992. Fusion of the Genera Boeckella and Pseudoboeckella (Copepoda) and revision of their species from South America and subAntartic islands. Revista Chilena de Historia Natural, 65: 17-63.

Beklioglu, M., Romo, S., Kagalou, I., Quintana, X. \& Bécares, E. (2007). State of the art in the functioning of shallow Mediterranean lakes: workshop conclusions. Hydrobiologia, 584: 317326. https://doi.org/10.1007/s10750-007-0577-x

Brucet, S., Boix, D., Gascón, S., Sala, J., Quintana, X. D., Badosa, A. \& Jeppesen, E. (2009). Species richness of crustacean zooplankton and trophic structure of brackish lagoons in contrasting climate zones: north temperate Denmark and Mediterranean Catalonia (Spain). Ecography, 32: 692-702. https://doi.org/10.1111/j.16000587.2009.05823.x

Cassie, R. (1971). Sampling and statistics. In: Edmonson, W. T. \& Winberg, G. G. (Eds.). A manual on methods for the assessment of secondary productivity in fresh waters. (pp. 174209). Blackwell, Oxford: ISP Handbook 17.
Caramujo, M. J. \& Boavida, M. J. (1999). Characteristics of the reproductive cycles and development times of Copidodiaptomus numidicus (Copepoda: Calanoida) and Acanthocyclops robustus (Copepoda: Cyclopoida). Journal of Plankton Research, 21: 1765-1778. https://doi.org/10.1093/plankt/21.9.1765

Carlson, R. E. (1977). A trophic state index for lakes. Limnology and Oceanography, 22: 361-369. https://doi.org/10.4319/lo.1977.22.2.0361

Chaparro, G., Marinone, M. C., Lombardo, R. J., Schiaffino, M. R., de Souza Guimarães, A. \& O'Farrell, I. (2011). Zooplankton succession during extraordinary drought-flood cycles: a case study in a South American floodplain lake. Limnologica, 41: 371-381. https://doi. org/10.1016/j.limno.2011.04.003

Del Ponti, O. D., Cabrera, G. C., Vignatti, A. M., \& Echaniz, S. A. (2015). Dynamics of the limnological parameters and zooplankton of La Brava, a shallow lake of the Atuel-SaladoChadileuvú-Curacó rivers system (La Pampa, Argentina). Applied Ecology and Environmental Sciences, 3: 193-199. https://doi.org/10.12691/ aees-3-6-5

Diovisalvi, N., Berasain, G., Unrein, F., Colautti, D., Fermani, P., Llames, M. E. \& Bustingorry, J. (2010). Chascomús: structure and functioning of a pampean turbid lake (Chascomús: estructura y funcionamiento de una laguna pampeana turbia). Ecología Austral, 20: 115-127.

Diovisalvi, N., Salcedo Echeverry, G. E., Lagomarsino, L. \& Zagarese, H. E. (2015). Seasonal patterns and responses to an extreme climate event of rotifers community in a shallow eutrophic Pampean lake. Hydrobiologia, 752: 125-137. https://doi.org/10.1007/s10750-014$1909-2$

Downing, J. A., Prairie, Y. T., Cole, J. J., Duarte, C. M., Tranvik, L. J., Striegl, R. G. \& Middelburg, J. J. (2006). The global abundance and size distribution of lakes, ponds, and impoundments. Limnology and Oceanography, 51: 2388-2397. https://doi.org/10.4319/lo.2006.51.5.2388

Echaniz, S. A., Vignatti, A. M. \& Bunino, P. C. (2008). El zooplancton de un lago somero hipereutrófico 
de la región central de Argentina: cambios después de una década. Biota Neotropica, 8: 63-71. http://dx.doi.org/10.1590/S167606032008000400005

Echaniz, S., Vignatti, A. \& Cabrera, G. (2009). Características limnológicas de una laguna turbia orgánica de la provincia de La Pampa y variación estacional del zooplancton. Biología Acuatica, 26: 71-82.

Echaniz, S. A. \& Vignatti, A. M. (2010). Diversity and changes in the horizontal distribution of crustaceans and rotifers in an episodic wetland of the central region of Argentina. Biota Neotropica, 10: 133-141. http://dx.doi. org/10.1590/S1676-06032010000300014

Echaniz, S. A., Vignatti, A. M., Cabrera, G. C., \& Paggi, S. B. J. D. (2012). Zooplankton richness, abundance and biomass of two hypertrophic shallow lakes with different salinity in central Argentina. Biota Neotropica, 12: 41-48. http:// dx.doi.org/10.1590/S1676-06032012000200005

Einsle, U. (1996). Copepoda: Cyclopoida: genera Cyclops, Megacyclops, Acanthocyclops. Guides to the Identification of the Microinvertebrates of the Continental Waters of the World. Amsterdam, SPB Academic Publishing

Elías-Gutierrez, M., Kotov, A. A. \& Garfias-Espejo, T. (2006). Cladocera (Crustacea: Ctenopoda, Anomopoda) from southern Mexico, Belize and northern Guatemala, with some biogeographical notes. Zootaxa, 1119: 1-27.

Ferrer, N. C., Cony, N. L., Fornerón, C. F. \& Piccolo, M. C. (2012). Caracterización del fitoplancton y estado trófico de la laguna Sauce Grande (Provincia de Buenos Aires, Argentina) en otoño de 2010. Biología Acuática, 27: 129-141.

Fornerón, C. F. (2016). Hidrografía de la laguna Sauce Grande (provincia de Buenos Aires) en época de sequía. Tesis Doctoral. Universidad Nacional del Sur, 219 pp.

Fornerón, C. F., Piccolo, M. C. \& Carbone, M. E. (2010a). Análisis morfométrico de la laguna Sauce Grande (Argentina). Revista Huellas, 14: 11-30.
Fornerón, C. F., Piccolo, M. C., Cony, N. L. \& Ferrer, N. C. (2010b). Hidrografía de la laguna Sauce Grande durante el otoño de 2010 (Provincia de Buenos Aires). Contribuciones Científicas Sociedad Argentina de Estudios Geográficos (GAEA), 22: 197-206

Freire, C. A., Cavassin, F., Rodrigues, E. N., Torres, A. H. \& McNamara, J. C. (2003). Adaptive patterns of osmotic and ionic regulation, and the invasion of fresh water by the palaemonid shrimps. Comparative Biochemistry and Physiology Part A, 136: 771-778. https://doi.org/10.1016/j. cbpb.2003.08.007

Frey, D. G. (1993). The penetration of cladocerans into saline waters. Hydrobiologia, 267: 233-248. https://doi.org/10.1007/BF00018805

González Sagrario, M. A. \& Ferrero, L. (2013). The trophic role of Cyphocharax voga (Hensel 1869) according to foraging area and diet analysis in turbid shallow lakes. Fundamental Applied of Limnology, 183: 75-88. http://dx.doi. org/10.1127/1863-9135/2013/0385

Grosman, F y González Castelain, J. (1996). Experiencias de alimentación y crecimiento con alevines de pejerrey (Odonthestes bonariensis) dirigidas a optimizar la siembra. Revista Ictiología, 4: 5-10.

Grosman, F, Sanzano, P y Agueria, D. (2002). Aspectos bioecológicos del pejerrey Odonthestes bonariensis de la laguna de Monte. Revista del Museo Argentino Ciencias Naturales nueva serie, 4: 13-23.

Hammer, U. T. (1986). Saline Lake Ecosystems of the World. Dordrecht: Springer.

Hoffmeyer, M. S. (2004). Decadal change in zooplankton seasonal succession in the Bahía Blanca estuary, Argentina, following introduction of two zooplankton species. Journal of Plankton Research, 26: 181-189. https://doi. org/10.1093/plankt/fbh023

Iglesias, C., Mazzeo, N., Meerhoff, M., Lacerot, G., Clemente, J. M., Scasso, F., Kruk, C., Goyenola, G., García-Alonso, J., Amsinck, S. L., Paggi, J. C., José de Paggi, S. \& Jeppesen, E. (2011). High 
predation is of key importance for dominance of small-bodied zooplankton in warm shallow lakes: evidence from lakes, fish enclosures and surface sediments. Hydrobiologia, 667: 133-147. http://dx.doi.org/10.1007/s10750-011-0645-0

Jensen, E., Brucet, S., Meerhoff, M., Nathansen, L. \& Jeppesen, E. (2010). Community structure and diel migration of zooplankton in shallow brackish lakes: role of salinity and predators. Hydrobiologia, 646: 215-229. http://dx.doi. org/10.1007/s10750-010-0172-4

Jeppesen, E., Jensen, J. P., Søndergaard, M. \& Lauridsen, T. (1999). Trophic dynamics in turbid and clearwater lakes with special emphasis on the role of zooplankton for water clarity. Hydrobiologia, 408: 217-231. https://doi. org/10.1023/A:1017071600486

Jeppesen, E. M., Søndergaard, A. R., Pedersen, K., Jürgens, A., Strzelczak, T. L., Lauridsen, N. \& Johansson, L. S. (2007a). Salinity Induced Regime Shift in Shallow Brackish Lagoons. Ecosystems, 10: 47-57. https://doi.org/10.1007/ s10021-006-9007-6

Jeppesen, E., Meerhoff, M., Jacobsen, B. A., Hansen, R. S., Søndergaard, M., Jensen, J. P., Lauridsen, T. L., Mazzeo, N. \& Branco, C. W. C. (2007b). Restoration of shallow lakes by nutrient control and biomanipulation-the successful strategy varies with lake size and climate. Hydrobiologia, 581: 269-285. https:// doi.org/10.1007/s10750-006-0507-3

Jeppesen, E., Kronvang, B., Meerhoff, M., Søndergaard, M., Hansen, K. M., Andersen, H. E. \& Olesen, J. E. (2009). Climate change effects on runoff, catchment phosphorus loading and lake ecological state, and potential adaptations. Journal of Environmental Quality, 38: 1930-1941. https://doi.org/10.2134/jeq2008.0113

Jeppesen, E., Nõges, P., Davidson, T. A., Haberman, J., Nõges, T., Blank, K. \& Johansson, L. S. (2011). Zooplankton as indicators in lakes: a scientificbased plea for including zooplankton in the ecological quality assessment of lakes according to the European Water Framework Directive (WFD). Hydrobiologia, 676: 279-297. https://doi. org/10.1007/s10750-011-0831-0
Jeppesen, E., Brucet, S. \& Naselli-Flores, L. (2015). Ecological impacts of global warming and water abstraction on lakes and reservoirs due to changes in water level and related changes in salinity. Hydrobiologia, 750: 201-227. http:// dx.doi.org/10.1007/s10750-014-2169-x

Kotov, A. A. (2003). Separation of Leydigia louisi Jenkin, 1934 from L. leydigi (Schoedler, 1863) (Chydoridae, Anomopoda, Cladocera). Hydrobiologia, 490: 147-168.

Lacroix, G. \& Lescher-Moutoue, F. (1991). Interaction effects of nutrient loading and density of young-of-the-year cyprinids on eutrophication in a shallow lake: an experimental mesocosm study. Memorie Dell'Istituto Italiano Di Idrobiologia, 48: 53-74.

Larson, C. A. \& Belovsky, G. E. (2013). Salinity and nutrients influence species richness and evenness of phytoplankton communities in microcosm experiments from Great Salt Lake, Utah, USA. Journal of Plankton Research, 35: 1154-1166. https://doi.org/10.1093/plankt/ fbt053

Leira, M. \& Cantonati, M. (2008). Effects of waterlevel fluctuations on lakes: an annotated bibliography. Hydrobiologia, 613: 171-184. https://doi.org/10.1007/s10750-008-9465-2

Margalef, R. (1983). Limnología. Barcelona: Omega.

Menu Marque, S. (2000). Datos biogeográficos y nuevas localidades de copépodos de la familia Cyclopidae (Copepoda, Cyclopoida) de la Argentina. Physis, 58: 37-41.

Nõges, T., Nõges, P., \& Laugaste, R. (2003). Water level as the mediator between climate change and phytoplankton composition in a large shallow temperate lake. Hydrobiologia, 506: 257-263. https://doi.org/10.1023/ B:HYDR.0000008540.06592.48

Olivier, S. R. (1962). Los cladóceros argentines con claves de las especies, notas biológicas y ditribución geográfica. Revista del Museo de La Plata (Nueva Serie, VII) Sección Zoología: 173-269. 
Paerl, H. W. \& Huisman, J. (2009). Climate change: a catalyst for global expansion of harmful cyanobacterial blooms. Environmental Microbiology Reports, 1: 27-37. https://doi. org/10.1111/j.1758-2229.2008.00004.x

Petrusek, A., Černý, M. \& Audenaert, E. (2004). Large intercontinental differentiation of Moina micrura (Crustacea: Anomopoda): one less cosmopolitan cladoceran? Hydrobiologia, 526: 73-81.

Pilati, A. (1997). Copépodos calanoideos de la provincia de La Pampa. Revista de la Facultad de Agronomía UNLPam, 9: 57-67.

Quirós, R. \& Drago, E. (1999). The environmental state of Argentinean lakes: An overview. Lakes and Reservoirs: Research and Management 4: 55-64. https://doi.org/10.1046/j.14401770.1999.00076.x

Quirós, R., Rennella, A., Boveri, M., Rosso, J. J. \& Sosnovsky, A. (2002). Factores que afectan la estructura y el funcionamiento de las lagunas pampeanas. Ecología Austral, 12: 175-185.

Remes Lenicov, M., \& Colautti, D. (2003). Laguna Sauce Grande, Partido de Monte Hermoso. Informe técnico No. 55. Campaña de relevamiento limnológicos e ictiológicos. Buenos Aires, Argentina.

Rocha Sousa, F. D. \& Elmoor-Loureiro, L. M. A. (2013). Cladocerans (Crustacea: Anomopoda and Ctenopoda) of the Sempre Vivas National Park, Espinhaço Range, Minas Gerais, Brazil. Checklist, 9: 4-8. https://doi.org/10.15560/9.1.4

Romo, S., Villena, M. J., Sahuquillo, M., Soria, J. M., Gimenez, M., Alfonso, T. \& Miracle, M. R. (2005). Response of a shallow Mediterranean lake to nutrient diversion: does it follow similar patterns as in northern shallow lakes? Freshwater Biology, 50: 1706-1717. https://doi. org/10.1111/j.1365-2427.2005.01432.x

Scheffer, M. \& van Nes, E. H. (2007). Shallow lakes theory revisited: various alternative regimes driven by climate, nutrients, depth and lake size. Hydrobiologia, 584: 455-466. https://doi. org/10.1007/s10750-007-0616-7

Sellner, K. G., Lacouture, B. R., \& Parrish, C.
R. (1988). Effects of increasing salinity on a cyanobacteria bloom in the Potomac River estuary. Journal of Plankton Research, 10: 49-61. https://doi.org/10.1093/plankt/10.1.49

Sosnovsky, A., Rosso, J. J. \& Quirós, R. (2010). Trophic interactions in shallow lakes of the Pampa plain (Argentina) and their effects on water transparency during two cold seasons of contrasting fish abundance. Limnetica, 29: 233-246.

Stenger-Kovács, C., Lengye, E., Buczkó, K., Tóth, F. M., Crossetti, L. O., Pellinger, A., \& Padisák, J. (2014). Vanishing world: alkaline, saline lakes in Central Europe and their diatom assemblages. Inland Waters, 4: 383-396.

Strickland, J. D. H. \& Parsons, T. R. (1968). A Practical Handbook of Sea-water Analysis. Bulletin of Fisheries Research Board of Canada, 19: 1-4.

Tan, C. O., \& Beklioglu, M. (2005). Catastrophiclike shifts in shallow Turkish lakes: a modeling approach. Ecological Modelling, 183: 425-434. https://doi.org/10.1016/j. ecolmodel.2004.07.033

TerBraak, C. J. (1988). CANOCO an extension of DECORANA to analyze species-environment relationships. Plant Ecology, 75(3): 159-160. https://doi.org/10.1007/BF00045629

Unrein, F., O'Farrell, I., Izaguirre, I., Sinistro, R., dos Santos Afonso, M. \& Tell, G. (2010). Phytoplankton response to $\mathrm{pH}$ rise in a $\mathrm{N}$-limited floodplain lake: relevance of N2-fixing heterocystous cyanobacteria. Aquatic Sciences, 72: 179-190. https://doi.org/10.1007/s00027009-0115-1

Vignatti, A., Echaniz, S. \& Martín, M. C. (2007). Zooplankton of three shallow lakes of different salinity and trophic state in the semiarid Pampean Region (Argentina). Gayana, 71: 34-48. http://dx.doi.org/10.4067/S071765382007000100005.

Vignatti, A., Cabrera, G. \& Echaniz, S. (2012). Changes in the zooplankton and limnological variables of a temporary hypo-mesosaline wetland of the central region of Argentina during its drying. Pan-American Journal of Aquatic Sciences, 7: 93-106. 